\title{
Initiatives and New Trends Towards Stem Education in Turkey
}

\author{
Adem Yılmaz ${ }^{1}$, Cihan Gülgün${ }^{2}$, Murat Çetinkaya ${ }^{3}$, Kamil Doğanay ${ }^{4}$ \\ ${ }^{1} \mathrm{PhD}$, Kastamonu University, Kastamonu, Turkey \\ ${ }^{2} \mathrm{PhD}$. Student, Kastamonu University, Kastamonu, Turkey \\ ${ }^{3}$ MSc. Student, Kastamonu, Turkey \\ ${ }^{4}$ Science Teacher, Kastamonu, Turkey \\ Correspondence: Adem Yılmaz, PhD, Kastamonu University, Kastamonu, Turkey.
}

Received: October 24, 2018

doi:10.11114/jets.v6i11a.3795
Accepted: October 27, $2018 \quad$ Online Published: November 29, 2018

URL: https://doi.org/10.11114/jets.v6i11a.3795

\begin{abstract}
STEM (Science, Technology, Engineering, Mathematics) Education; Is an educational approach that many countries in the world have included in their curricula that allow learners to view the knowledge they learn in science, technology, engineering and mathematics courses, aiming at transforming theoretical knowledge into practice, product and innovative inventions. It is aimed to be able to adapt easily to the qualities of the business life thanks to these skills when the STEM trained individuals enter into the business world, as well as being an approach that is based on giving the skills of STEM education, production and invention. Within the scope of the study, attempts were made to investigate the initiatives and new trends of STEM education from 2010 until the day. Document analysis and thematic content analysis (meta-synthesis) method was used in the research process. Thematic content analysis; Analyze, synthesize and interpret the findings of more than one research on the same subject, with a critical point of view, in contrast to the theme or templates specified and raw data. During the research; Articles, theses, reports and reports which are reached from various sources in the national and international literature have been examined and a wide-scale resource has been created by considering every point related to the contents of the work. The results of the research were examined under various headings and a broad framework was established and recommendations were made.
\end{abstract}

Keywords: STEM, meta-synthesis, science, thematic content analysis

\section{Introduction}

Efforts to acquire new and different information have always existed in human life. With the development of technological developments in the 21 st century, access to information has become easier and knowledge has begun to emerge as a new name. Today's world expects to have a productive structure from people. For people to be able to present their productivity, different programs that constantly encourage their thinking, questioning, designing and creativity need to be passed down (Akgündüz, et al., 2015). Naturally owned education systems should also be included in this way to meet today's needs (Çakıroğlu, 2016).

In the 21st century, developments in science and technology have become a race and have been accelerated. This, in turn, has forced developed countries to invest more in know-how, engineering and innovation. The European Union (EU) published a review report in 2007 entitled "Science Education Now: Renewed Pedagogy for the Future of Europe" (Robert, 2012). This report touched on the problems that Europe is experiencing in science and technology education and it has been pointed out that especially young people 's knowledge about science is declining significantly. The fact that the basis of science education is based on inquiry has necessitated the establishment of more networks in order to increase the motivation and cooperation of the stakeholders (teachers, students, experts, parents, etc.). These obligations have led to the development of an educational approach centering on the needs of contemporary business life and creating new projects in the US and EU countries, which provide technical knowledge and skills to be delivered, make students a part of life instead of preparing them for life. STEM education, a new system for meeting the needs of the mentioned needs, has been developed and passed on to life (Gülhan \& Şahin, 2016).

STEM education; Science, Technology, Engineering and Mathematics have emerged with abbreviations of English initials. Teachers and students improve their self-sufficiency in many fields (physical, cultural, social) by developing themselves and acquiring a critical structure and solving the problems they encounter more easily (Çorlu \& Aydın, 
2016). When it comes to time, it is seen that the individuals who enter the business world are able to adapt more easily to the qualities they deserve thanks to these superior skills they have (Bybee, 2011).

STEM education aims to approach the problems encountered by students with a multidisciplinary approach and to acquire knowledge and skills through a holistic educational structure (Şahin, Ayar \& Adıgüzel, 2014; Yılmaz, 2016). STEM education is considered as a multidisciplinary approach starting from the beginning of the school and continuing up to higher education and covering the whole education process (Çorlu \& Aydin, 2016). According to Lederman \& Niess (1997), the multidisciplinary educational approach refers to an unfragmented construction, which is analogous to the formation of compounds in a chemical reaction. Just as compounds have different properties than self-styling elements, when disciplines are integrated into different modules, they produce a much clearer picture than what they have (Lederman \& Niess, 1997).

STEM education can be considered as a training process involving the use of everyday life, raising living standards and critical thinking by bringing together diverse and connected disciplines and providing better quality learning and resulting learning outcomes (Ylldırım \& Altun, 2015). STEM education encourages students and trainers to learn directly (Çakıroğlu, 2016). For example, students can design and implement projects they have produced in their own minds (Özdemir, 2016). Studies on STEM education; STEM education is very important in terms of enabling the theoretical knowledge in science, technology, engineering and mathematics to be applied and transformed into a product after a certain period. (Çorlu, 2013; Yılmaz, Gülgün \& Çağlar, 2017).

STEM education is an educational system that provides learners and educators with problem-solving skills (Roberts, 2012). This system argues that students' success and motivation can be enhanced, especially in real world issues (Honey, Pearson \& Schweingruber, 2014). STEM education, which supports mental process skills, entrepreneurship and product formation ability, constantly encourages people to move into action at the point of realizing their dreams and is effective in creating awareness (Özdemir, 2016; Gülgün, Y1lmaz \& Çağlar, 2017). STEM education focuses on global literacy skills.

These abilities are; creative and critical thinking, problem solving and teamwork. It is very important for students and teachers to win these talents. At this point, the role and importance of teachers should be increased, and students should be guided and guided rather than giving theoretical knowledge in Science, Technology, Engineering and Mathematics courses to reach a higher level of thinking, production and invention (Çelik, Pektaş \& Karamustafaoğlu, 2018). While gaining these behaviors, it is necessary to provide environments in the education system that will prevent students from being afraid of making mistakes and incompleteness and that will increase their courage.

In short, STEM education is not a single outcome process. It is an educational system that provides the students with the necessary incentive to do better when the teacher supports the student constantly and everywhere and when the desired product is reached (Özdemir, 2016; Yılmaz \& Bayrakçeken, 2015).

People develop tools that will make their lives easier throughout their lives, and while they develop these tools, they transmit generations of knowledge that they have learned. The theoretical knowledge often held in material design and tool development processes is second to none in terms of application activities. This situation is similar in our educational experiences (Daugherty, 2009, 2012; Y1lmaz, 2012, 2016).

Especially in science education, this situation is more clearly seen. While education and training programs are being developed, the design process is not given the necessary attention and the background is transforming the information into a concrete structure. In this context, an education model that emphasizes the application and design aspects of education will undoubtedly open a more permanent and productive education for students (Güzey, Harwell \& Moore, 2014; Y1lmaz, 2012; Gülgün, 2014). The same is true of science education, one of the areas with an effective educational need. The basis of science education lies in solving the problems we face in our daily lives and gaining the ability to manage these processes well. In recent years, the notion of integration, a popular concept, has emerged to develop different perspectives against problems.

According to Lederman \& Niess (1997), integration refers to making an unfragmented whole. Just like compounds that come in a chemical reactionary form. Just as compounds show different chemical properties than their constituent elements, when they are integrated into one another in different disciplines they will tend to show new properties unlike fragments. This is the same system that is called STEM and advocates the disciplines of Science, Technology, Engineering, Mathematics together (Gülhan \& Şahin, 2016). STEM education, which has developed very rapidly in our country in recent years, aims to educate future designer and productive students in a creative way to solve problem-solving processes (Roberts, 2012). STEM education aims at approaching the problems encountered in daily life with a multidisciplinary approach (Şahin, Ayar \& Adıgüzel, 2014; Honey, Pearson \& Schweingruber, 2014). The positive effects of the acquisition of engineering skills in the primary education process can be categorized as follows (Katehi, Pearson \& Feder, 2009); 
1. Positive development of success in science and mathematics education.

2. Increase awareness of engineering.

3. Development of designing skills.

4. Increase in occupational interest in engineering and science.

5. Provision of technology literacy.

\section{Problem of Research}

Today, when technology and information are produced rapidly, the values and needs of society are changing and renewing in the same parallel. As a result of these changes and innovations, the need for educated people is increasing day by day and the reconsideration of educational policies is on the agenda (Çiltaş, Güler \& Sözbilir, 2012). Scientific work affects all areas in consequence of consequences and takes an important place in the determination of country policies and serves as guidance in professional activities.

From this point of view, the studies carried out for the field of education are mostly in the form of textbooks, articles, handbooks. However, this situation only creates an information store. The purpose of their studies on educational sciences is slightly different. These publications can also be considered as an information repository suitable for the field of education to be used (McMillan \& Schumacher, 2009). Scientific research often desires to serve social purposes. Research is an attempt to answer the question of why, how, when, where and where to ask about the factors that cause a problem, such as defining the society, assimilating, trying to reveal the patterns and associations related to the connected variables (Özdamar, 2003).

According to these characteristics, scientific studies can only be done with the help of data (Ercan \& Kan, 2004). Meta-synthesis studies and thematic content analysis studies play an important role in the acquisition of data in a scientific study, in analyzing and evaluating the obtained data. For this purpose, studies on STEM education since 2010 have been examined using thematic content analysis and meta-synthesis method and various suggestions have been made. In line with this objective, the following questions have been tried to be answered. Accordingly, in line with the main themes determined in the field of science, technology and mathematics education;

1. In which areas did STEM education studies mostly take place?

2. What kinds of samples have been used frequently in STEM education studies?

3. How are the sample sizes used in STEM education studies?

4. What are the data collection tools used in STEM education studies?

5. What are the data analysis methods used in STEM education studies?

6. In which regions of Turkey were STEM studies conducted?

7. Was the validity and reliability analysis done in STEM education studies?

\section{Research Focus}

STEM education has been included in development policies in many countries and has already taken its place in long-term strategic plans and refers to three different themes in the development process: acquisition of problem-solving skills, innovation and design (Hernandez, et al., 2014). It is undoubtedly known that knowledge is the most important power in the developing world and that it has a great prospect in terms of competitiveness in the international arena (Çorlu, Capraro \& Capraro, 2014). From this point of view, it can be said that the professions developed on the basis of STEM are the criteria of a state innovative, innovative and indispensable for increasing living standards (Langdon, McKittrick, Beede, Khan \& Doms, 2011; Yılmaz, Gülgün \& Çă̆lar, 2017).

If students in our country are required to make STEM-centered career choices from an early age, the education system should be intervened in a timely manner and the community should be aware of this issue (Moore \& Richards, 2012). However, classroom environments designed to fit the traditional structure have increased the reaction and indifference to STEM, rather than motivating students to participate in STEM education (Roberts, 2012). A classroom environment that focuses on STEM activities and applications for solving this problem will be more appropriate to achieve planned goals.

\section{Methodology of Research}

\section{General Background of Research}

This is a thematic content analysis (meta-synthesis) study. Thematic content analysis; (Walsh \& Downe, 2005). This study examines the findings of many studies on similar topics with the help of pre-defined themes or templates, and 
with a critical perspective different from raw data. With this comprehensive feature, thematic content analysis also provides a rich reference to the researcher in terms of access to more work because it enables qualitative re-synthesis of common and similar aspects of studies that deal with various aspects of a given topic (Çalık, Ayas \& Ebenezer, 2005). Compared with meta-analysis and descriptive content analysis, the number of studies (sample size) generally limited in these studies is limited (Çalık \& Sözbilir, 2014).

Sample of Research

In the process of gathering the data, it was first decided to examine the articles published between 2010-2017 of the magazines broadcasting in Turkey within the scope of the research. The reason for choosing 2010 as the starting year of the study is that the studies on STEM education in our country increased rapidly especially after 2010 and the academic field showed a tendency towards this direction. In the selection of the journals published by the books, it was noted that there were TUBITAK Dergipark and articles focused on science education.

It is considered that the assumption that the articles indexed in the databases are originating from Turkey and that it is going through an evaluation process and considering the publications in the journals will have more reliable results. During the publication of the articles, over 200 articles of STEM / STEMA / STEM + A were published which were accessed by their own means and published in full text, while free and open access articles were accessed via their web pages.

In addition, pre-evaluation articles co-authored by researchers were re-examined within the framework of "inclusion in research and exclusion from research" criteria, so that a total of 20 articles were eligible for consideration. Detailed information on the code and scope of the articles taken into consideration in the scope of the research is presented in Appendix 1.

\section{Instrument and Procedures}

Criteria taken into account in the inclusion and non-investigation of the articles:

- Publishing in selected articles: Attention has been paid to publishing only articles selected in the selected journals.

- Being published in the specified years: It has been noted that the articles in the journals examined are published between 2010-2017.

- The need for STEM education in editions: Only STEM education studies were examined in this thematic content analysis study.

- Appropriateness to the research field: STEM studies studied within the scope of this research were included only in the analysis of issues related to science, engineering, technology and mathematics education.

- Suitability of the sample: It has been noted that the samples included in the thematic content analysis are selected only from the Turkish borders.

\section{The main themes that include thematic content analysis and coding method}

Within the scope of the research, all researchers worked together in the coding of the articles to be analyzed the thematic content and the themes were determined. Accordingly, the articles included in the research were examined one by one by the researchers and main themes and sub-themes were determined. The determined main and sub themes are handled in detail in all directions and coded into tables (Table 1, Table 2, Table 3, Table 4).

Table 1. Codes and main themes

\begin{tabular}{ll}
\hline Codes & Main theme \\
\hline GIYÇ & Opinion, Idea, Thought, Emotion, Inner Work \\
MTYÇ & Media / Material Design Studies \\
ABYÇ & Academic Achievement \\
TAYÇ & Attitude, Perception-oriented studies \\
EÖYÇ & Integrated (Integrated) Teaching oriented studies \\
DRYÇ & Works for the Review and Review Report \\
\hline
\end{tabular}

Once the main and sub-themes in the study were established, all researchers individually examined each of the articles they chose randomly from each of the identified main themes to ensure the reliability of the study. As a result of the individual studies made, the data were compared and it was seen that the researchers were in agreement with the majority of them. In addition, when any discrepancies were found in the comparisons made, the related articles were 
examined together by the researchers and the necessary corrections were made to resolve the inconsistencies.

Attention has also been paid to ensuring the validity as well as the reliability in the research. For this purpose, Sandelowski \& Barroso (2007) conducted the three validity tests described in the literature to validate meta-synthesis;

1. Descriptive validity: A type of validity that does not define the correctness of the data based on facts. This is a meaningful and accurate description of each rapport that is used in the study.

2. Interpretative Validity: Provides full and accurate representation of the researchers' perceptions of perspective.

3. Theoretical validity: refers to the reliability of the researcher in the interpretation of findings. This means that, depending on the combination of the information, the method used to interpret the data.

\section{Results of Research}

In the study, the articles included in the thematic content analysis were classified as engineering and design "MT1", chemistry and mathematics education articles "KM1" in the form of science education articles "FB1, FB2 ...", ranked according to subject areas and published years under the determined main themes. Studies in the form of "TA1" for the perception, "M1" for the engineering education, "SO1" for the teaching of the classroom teacher and "D1, D2 ..." for the preparation of the review report. Therefore, these code lines have been taken into consideration in the analysis. Then, for each main theme determined within the scope of the research, the findings were presented in the order of author name, publication year, publication code, sample type, sample size, method, application location, data collection tools, data analysis, validity analyzes and reliability analyzes (Table 1, Table 2, Table 3, Table 4).

Accordingly, the findings obtained from the analyzes are presented below. When Table 2 is examined, it is seen that there are 8 articles belonging to the main theme of GIYC and 6 articles in the articles are made in the field of science education, 1 article is made in the field of classroom teaching and 1 article is made in the field of chemistry and mathematics education. When we look at the main theme of MTJC, it is understood that there are 3 articles on this main theme, both articles were made in the field of science education, and 1 of them were made in the field of engineering and design education. Looking at the main theme of ABYC, it is seen that there are only 2 articles in this subject and these two articles are made in the field of science education. When we look at the main theme of TAYC, it is determined that there are 3 articles and these articles are equally in the field of science education, attitude and perception education, engineering education. When examining the main theme of the EOYC, it was determined that there was only one article and that this article was made in the field of science education. Finally, when the main theme of the DRYC is examined, it is determined that there are 3 articles and the articles are prepared in the form of compilation and examination report. When the articles included in the thematic content analysis were examined in terms of the type of sample (Table 3); It is understood that the vast majority of the studies are carried out with primary and undergraduate students and again a small number of educators and secondary students are involved. However, findings in terms of sample size suggest that the articles are predominantly studied with 20-50 participants, with 100 and above participants, and the remainder with sample participants 1-20. When the articles included in the thematic content analysis are examined from the perspective of the research method, it is seen that qualitative and quantitative research methods are frequently used and these ratios are close to each other, but mixed method researches are seen to be less preferred.

On the other hand, when the studied regions were examined, it was seen that the studies were carried out mainly in the ones carrying the metropolitan characteristics, and in the non-urban areas, the studies were made less. When the articles included in the thematic content analysis are examined in terms of data collection tools, it is seen that they mainly use academic achievement test, attitude and perception scales, Likert type questionnaire and scales, semi-structured interview and observation forms, document analysis and comparative field notes. When the articles included in the thematic content analysis were analyzed in terms of data analysis (Table 4), it was determined that the content analysis technique was frequently preferred, that comparative analyzes and factor analyzes were performed, parametric and nonparametric analysis techniques were used and that negotiations were classified by transcript. Concerning validity and reliability analyzes; It has been observed that all the articles are paid attention to the steps of validity and reliability and there are not many deficiencies in this issue. 
Table 2. Classification of data by author, article number, publication year, publication code, and main theme

\begin{tabular}{|c|c|c|c|c|}
\hline AUTHORS & $\begin{array}{l}\text { ARTICLE } \\
\text { NUMBER }\end{array}$ & $\begin{array}{l}\text { PUBLISHING } \\
\text { YEAR }\end{array}$ & $\begin{array}{l}\text { CLASSIFICATION } \\
\text { CODE }\end{array}$ & MAIN THEME \\
\hline ERCAN \& ŞAHIN (2015) & 7 & 2015 & FB3 & ACADEMIC SUCCESS \\
\hline YILDIRIM \& ALTUN (2015) & 15 & 2015 & FB8 & ACADEMIC SUCCESS \\
\hline AKGÜNDÜZ, AYDENIZ, ÇAKMAKÇI, CAAVAŞ, ÇORLU, ÖNER \& ÖZDEMIR (2015) & 12 & 2015 & D1 & COM PILATION AND REVIEW REPORT \\
\hline BATI, ÇALIŞKAN \& YETiŞiR (2017) & 13 & 2017 & $\mathrm{D} 2$ & COMPILATION AND REVIEW REPORT \\
\hline TEZEL \& YAMAN (2017) & 18 & 2017 & D3 & COMPILATION AND REVIEW REPORT \\
\hline ÇORLU, CAPRARO \& ÇORLU (2015) & 11 & 2015 & FB6 & INTEGRATED EDUCATION \\
\hline EROĞLU \& BEKTAŞ (2016) & 1 & 2016 & FB1 & OPINION, IDEAS, THOUGHTS, EMOTION, BELIEFS \\
\hline ASLAN-TUTAK, AKAYGÜN \& TEZSEZEN (2017) & 3 & 2017 & KM1 & OPINION, IDEAS, THOUGHTS, EMOTION, BELIEFS \\
\hline ALTAN, YAMAK \& KIRIKKAYA (2016) & 8 & 2016 & FB4 & OPINION, IDEAS, THOUGHTS, EMOTION, BELIEFS \\
\hline HACIOMEROǦLU \& BULUT (2016) & 9 & 2016 & SÖ1 & OPINION, IDEAS, THOUGHTS, EMOTION, BELIEFS \\
\hline BUYRUK \& KORKMAZ (2016) & 14 & 2016 & FB7 & OPINION, IDEAS, THOUGHTS, EMOTION, BELIEFS \\
\hline ÇINAR, PIRASA, UZUN \& ERENLER (2016) & 16 & 2016 & FBg & OPINION, IDEAS, THOUGHTS, EMOTION, BELIEFS \\
\hline KEÇECi, ALAN \& ZENGIN (2017) & 17 & 2017 & FB10 & OPINION, IDEAS, THOUGHTS, EMOTION, BELIEFS \\
\hline GÜLGÜN, YILMAZ \& ÇAĞLAR (2017) & 20 & 2017 & FB12 & OPINION, IDEAS, THOUGHTS, EMOTION, BELIEFS \\
\hline BARAN, CANBAZOǦLU-BiLici \& MESUTOĞLU (2015) & 2 & 2015 & MT1 & MEDIA / MATERIAL DESIGN \\
\hline ŞAHIN, AYAR \& ADIGÜZEL (2014) & 10 & 2014 & $\mathrm{FB5}$ & MEDIA / MATERIAL DESIGN \\
\hline YILMAZ, GÜLGÜN \& ÇAĞLAR (2017) & 19 & 2017 & FB11 & MEDIA / MATERIAL DESIGN \\
\hline GÜLHAN \& ŞAHIN (2016) & 4 & 2016 & TA1 & ATTTUDE \& PERCEPTION \\
\hline MARULCU\&SUNGUR (2012) & 5 & 2012 & M1 & ATTIUDE \& PERCEPTION \\
\hline YAMAK, BULUT \& DÜNDAR (2014) & 6 & 2014 & FB2 & ATTTUDE \& PERCEPTION \\
\hline
\end{tabular}

Table 3. Classification of data by type of sample - size, method of research and application place

\begin{tabular}{|c|c|c|c|c|c|c|c|c|c|c|c|c|c|c|c|c|c|}
\hline \multirow[b]{2}{*}{ AUTHORS } & \multirow[b]{2}{*}{ 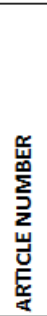 } & \multirow[b]{2}{*}{ 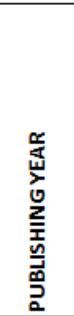 } & \multirow[b]{2}{*}{ 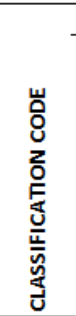 } & \multicolumn{4}{|c|}{ SAMPLINGTYPE } & \multicolumn{6}{|c|}{ SAMPLING SIZE } & \multicolumn{3}{|c|}{ METHOD } & \multirow[b]{2}{*}{ 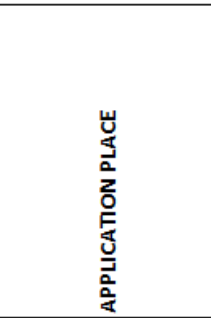 } \\
\hline & & & & 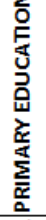 & 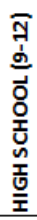 & 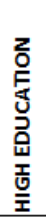 & $\begin{array}{l}\text { 号 } \\
\text { 폰 } \\
\text { 出 } \\
\end{array}$ & $\stackrel{4}{i}$ & $\stackrel{9}{b}$ & 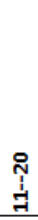 & $\begin{array}{c}\text { फ़ } \\
\text { ஸे } \\
\text { N }\end{array}$ & ঙे & \$े & 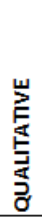 & 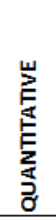 & 啇 & \\
\hline ERCAN \& ŞAHIN (2015) & 7 & 2015 & FB3 & $\checkmark$ & - & - & - & - & - & - & $\checkmark$ & - & - & - & - & $\checkmark$ & ISTANBUL CITY \\
\hline YILDIRIM \& ALTUN (2015) & 15 & 2015 & FB8 & - & - & $\checkmark$ & - & - & - & - & - & $\checkmark$ & - & - & $\checkmark$ & - & MUŞ CITY \\
\hline $\begin{array}{c}\text { AKGÜNDÜZ, AYDENIZ, ÇAKM AKÇI, ÇAVAŞ, ÇORLU, ÖNER } \\
\text { \& ÖZDEMIR (2015) }\end{array}$ & 12 & 2015 & $\mathrm{D} 1$ & - & - & $\checkmark$ & - & - & - & - & - & - & $\checkmark$ & $\checkmark$ & $\checkmark$ & $\checkmark$ & ISTANBUL CITY \\
\hline BATI, ÇALIŞKAN \& YETiŞiR (2017) & 13 & 2017 & D2 & - & - & - & $\checkmark$ & - & - & - & - & - & $\checkmark$ & $\checkmark$ & - & - & ANKARA CITY \\
\hline TEZEL \& YAMAN (2017) & 18 & 2017 & D3 & - & - & $\checkmark$ & - & - & - & - & - & - & $\checkmark$ & $\checkmark$ & - & - & ESKIŞEHIR CITY \\
\hline ÇORLU, CAPRARO \& ÇORLU (2015) & 11 & 2015 & FB6 & - & - & $\checkmark$ & - & - & - & - & - & - & $\checkmark$ & - & - & $\checkmark$ & ANKARA CITY \\
\hline EROǦLU \& BEKTAŞ (2016) & 1 & 2016 & FB1 & - & - & - & $\checkmark$ & $\checkmark$ & - & - & - & - & - & $\checkmark$ & - & - & KAYSERI CITY \\
\hline ASLAN-TUTAK, AKAYGÜN \& TEZSEZEN (2017) & 3 & 2017 & KM1 & - & - & $\checkmark$ & - & - & - & - & $\checkmark$ & - & - & - & $\checkmark$ & - & ISTANBUL CITY \\
\hline ALTAN, YAMAK \& KIRIKKAYA (2016) & 8 & 2016 & FB4 & - & - & $\checkmark$ & - & - & $\checkmark$ & - & - & - & - & $\checkmark$ & - & - & SINOP CITY \\
\hline HACIOMEROĞLU \& BULUT (2016) & 9 & 2016 & SÖ1 & - & - & $\checkmark$ & - & - & - & - & - & - & $\checkmark$ & - & $\checkmark$ & - & ÇANAKKALE CITY \\
\hline BUYRUK \& KORKMAZ (2016) & 14 & 2016 & FB7 & - & - & $\checkmark$ & - & - & - & - & - & - & $\checkmark$ & - & $\checkmark$ & - & AMASYA CITY \\
\hline ÇINAR, PIRASA, UZUN \& ERENLER (2016) & 16 & 2016 & FB9 & - & - & $\checkmark$ & - & - & - & - & $\checkmark$ & - & - & $\checkmark$ & $\checkmark$ & - & RIZE CITY \\
\hline KEÇECI, ALAN \& ZENGIN (2017) & 17 & 2017 & FB10 & $\checkmark$ & - & - & - & - & - & - & $\checkmark$ & - & - & $\checkmark$ & $\checkmark$ & - & ELAZIĞ CITY \\
\hline GÜLGÜN, YILMAZ \& ÇAĞLAR (2017) & 20 & 2017 & FB12 & - & - & - & $\checkmark$ & - & - & - & - & - & $\checkmark$ & - & - & $\checkmark$ & KASTAMONU CITY \\
\hline $\begin{array}{l}\text { BARAN, CANBAZOĞLU-BiLICI \& MESUTOĞLU } \\
\qquad(2015)\end{array}$ & 2 & 2015 & MT1 & $\checkmark$ & - & - & - & - & - & - & $\checkmark$ & - & - & - & - & $\checkmark$ & ANKARA CITY \\
\hline ŞAHIN, AYAR \& ADIGÜZEL (2014) & 10 & 2014 & FB5 & $\checkmark$ & - & - & - & - & - & - & - & - & $\checkmark$ & $\checkmark$ & - & - & ISTANBUL /AMERIKA \\
\hline YILMAZ, GÜLGÜN \& ÇAĞLAR (2017) & 19 & 2017 & FB11 & $\checkmark$ & - & - & - & - & - & - & $\checkmark$ & - & - & - & - & $\checkmark$ & KASTAMONU CITY \\
\hline GÜLHAN \& ŞAH IN (2016) & 4 & 2016 & TA1 & $\checkmark$ & - & - & - & - & - & - & - & $\checkmark$ & - & - & $\checkmark$ & - & ISTANBUL CITY \\
\hline MARULCU\&SUNGUR (2012) & 5 & 2012 & M1 & - & - & $\checkmark$ & - & - & - & - & $\checkmark$ & - & - & $\checkmark$ & $\checkmark$ & - & KAYSERI CITY \\
\hline \multirow[t]{2}{*}{ YAMAK, BULUT \& DÜNDAR (2014) } & 6 & 2014 & FB2 & $\checkmark$ & - & - & - & - & - & $\checkmark$ & - & - & - & - & $\checkmark$ & - & ANKARA CITY \\
\hline & & & TOTAL & 7 & 0 & 10 & 3 & 1 & 1 & 1 & 7 & 2 & 8 & 9 & 10 & 6 & \\
\hline
\end{tabular}


Table 4. Classification of data by data collection tools, types of data analysis, validity and reliability

\begin{tabular}{|c|c|c|c|c|c|c|c|c|c|}
\hline \multirow[b]{2}{*}{ AUTHORS } & \multirow{2}{*}{ 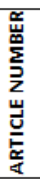 } & \multirow{2}{*}{ 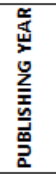 } & \multirow{2}{*}{ 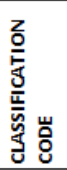 } & \multirow[b]{2}{*}{ DATA COLLECTION TOOLS } & \multirow[b]{2}{*}{ DATA ANALYSIS } & \multicolumn{2}{|c|}{$\begin{array}{l}\text { VALIDITY } \\
\text { ANALYSIS }\end{array}$} & \multicolumn{2}{|c|}{$\begin{array}{l}\text { REUABIUTY } \\
\text { ANALYSIS }\end{array}$} \\
\hline & & & & & & 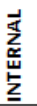 & 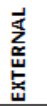 & 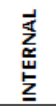 & 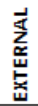 \\
\hline ERCAN \& ŞAHIN (2015) & 7 & 2015 & FB3 & ACADEMIC SUCCESS TEST, INTERVIEW & PARAMETRIC TESTS & $\checkmark$ & $\checkmark$ & $\checkmark$ & $\checkmark$ \\
\hline YILDIRIM \& ALTUN (2015) & 15 & 2015 & FB8 & ACADEMIC SUCCESS TEST & PARAMETRIC TESTS & $\checkmark$ & $\checkmark$ & $\checkmark$ & $\checkmark$ \\
\hline $\begin{array}{l}\text { AKGÜNDÜZ, AYDENIZ, CCAKMAKÇI, CCAVAŞ, ÇORLU, ÖNER } \\
\text { \& ÖZDEMIR (2015) }\end{array}$ & 12 & 2015 & D1 & DOCUMENT ANALYSIS & COMPARATIVE ANALYSIS & $\checkmark$ & $\checkmark$ & $\checkmark$ & $\checkmark$ \\
\hline TEZEL \& YAMAN (2017) & 18 & 2017 & D3 & DOCUMENT ANALYSIS & COMPARATIVE ANALYSIS & $\checkmark$ & $\checkmark$ & $\checkmark$ & $\checkmark$ \\
\hline ÇORLU, CAPRARO \& ÇORLU (2015) & 11 & 2015 & FB6 & LIKERT TYPE SURVEY, COMPARISON & FACTOR ANAL YSIS (EFA, CFA) & $\checkmark$ & $\checkmark$ & $\checkmark$ & $\checkmark$ \\
\hline EROĞLU \& BEKTAŞ (2016) & 1 & 2016 & FB1 & SEMICONDUCTED CONVERSATION & TRANSCRIPT & $\checkmark$ & $\checkmark$ & $\checkmark$ & $\checkmark$ \\
\hline ASLAN-TUTAK, AKAYGÜN \& TEZSEZEN (2017) & 3 & 2017 & KM1 & OPEN-ENDED QUESTIONS, SCALE & CONTENT ANALYSIS & $\checkmark$ & $\checkmark$ & $\checkmark$ & $\checkmark$ \\
\hline ALTAN, YAMAK \& KIRIKKAYA (2016) & 8 & 2016 & FB4 & SEMICONDUCTED CONVERSATION & CONTENT ANALYSIS, TRANSCRIPTION & $\checkmark$ & $\checkmark$ & $\checkmark$ & $\checkmark$ \\
\hline HACIOMEROĞLU \& BULUT (2016) & 9 & 2016 & sö1 & LIKERT TYPE SCALE & FACTOR ANAL YSIS (EFA, CFA) & $\checkmark$ & $\checkmark$ & $\checkmark$ & $\checkmark$ \\
\hline BUYRUK \& KORKMAZ (2016) & 14 & 2016 & FB7 & LIKERT TYPE SCALE & FACTOR ANAL YSIS (EFA, CFA) & $\checkmark$ & $\checkmark$ & $\checkmark$ & $\checkmark$ \\
\hline KEÇECI, ALAN \& ZENGIN (2017) & 17 & 2017 & FB10 & ATTITUDE MEASUREMENT & CONTENT ANALYSIS & $\checkmark$ & $\checkmark$ & $\checkmark$ & $\checkmark$ \\
\hline GÜLGÜN, YILMAZ \& ÇAĞLAR (2017) & 20 & 2017 & FB12 & $\begin{array}{c}\text { SEMICONDUCTOR CONSTRUCTION, LIKERT } \\
\text { TYPE SCALE }\end{array}$ & $\begin{array}{l}\text { NON-PARAMETERIC TESTS, } \\
\text { TRANSKRIPT }\end{array}$ & $\checkmark$ & $\checkmark$ & $\checkmark$ & $\checkmark$ \\
\hline BARAN, CANBAZOǦLU-BiLIICI\& MESUTOĞLU (2015) & 2 & 2015 & MT1 & OPEN ENDED QUESTIONS, OBSERVATION FORM & PRODUCT ASSESSMENT METHOD & $\checkmark$ & $\checkmark$ & $\checkmark$ & $\checkmark$ \\
\hline ŞAHIN, AYAR \& ADIGÜZEL (2014) & 10 & 2014 & FB5 & OBSERVATION, SIGHT NOTES, INTERVEW & CONTENT ANAL YSIS, TRANSCRIPTION & $\checkmark$ & $\checkmark$ & $\checkmark$ & $\checkmark$ \\
\hline YILMAZ, GÜLGÜN \& ÇAĞLAR (2017) & 19 & 2017 & FB11 & $\begin{array}{l}\text { SEMI-CONFIGURED INTERVIEW, ATTITUDE } \\
\text { SCALE, OBSERVATION, SUCCESS TEST }\end{array}$ & $\begin{array}{l}\text { PARAMETRIC TESTING, } \\
\text { TRANSCRIPTION }\end{array}$ & $\checkmark$ & $\checkmark$ & $\checkmark$ & $\checkmark$ \\
\hline GÜLHAN \& ŞAHIN (2016) & 4 & 2016 & TA1 & PERCEPTION TEST, ATTITUDE TEST & NON-PARAMETRIC TESTS & $\checkmark$ & $\checkmark$ & $\checkmark$ & $\checkmark$ \\
\hline MARULCU\& SUNGUR (2012) & 5 & 2012 & M1 & LIKERT TYPE SCALE & CONTENT ANALYSIS & $\checkmark$ & $\checkmark$ & $\checkmark$ & $\checkmark$ \\
\hline YAMAK, BULUT \& DÜNDAR (2014) & 6 & 2014 & FB2 & SCALE AND SCIENTIFIC PROCESS SKILLS TEST & PARAMETRIC TESTS & $\checkmark$ & $\checkmark$ & $\checkmark$ & $\checkmark$ \\
\hline
\end{tabular}

\section{Discussion and Conclusions}

This research shows that there are several studies on STEM education in Turkey and that studies are gaining momentum mainly between 2012-2017. In addition, most of the studies carried out in the field of education constitute studies carried out in the field of science education. In addition to this, we see that studies are also made for engineering education, compilation studies, classroom teacher education and mathematics education. The results show that STEM education is integrated and preferred more easily and more consistently in the study of science lessons. Studies show that the main theme of the study is the most preferred work of opinion, opinion, thought and belief.

We can say that this is followed by material design, attitude and perception, compilation studies and academic success studies respectively. Among the reasons for not being preferred are the fact that opinions and ideas work quickly, easily and economically. When studies on STEM education are examined in terms of sample size, it is seen that between 20-50 participants and over 100 participants are frequently preferred. It can be argued that these samples were preferred because of their need for large samples of opinions and ideas.

In addition, it is seen that the students who are in the age of primary school and those who are at the university level are often preferred in the selection of participants. It can be argued that fewer studies on secondary education and teachers are due to the difficulty and difficulty of the preparation and implementation stages of this sample group. When studies are examined in terms of research methods, it is seen that mixed studies where qualitative and quantitative studies are frequently used are less preferred. The reason for the small number of mixed surveys is that the process is laborious and requires a good knowledge accumulation. In addition, when data collection tools of studies are examined, it is noteworthy that they are frequently used in document analysis, academic achievement test, attitude tests, opinion tests, scales, observations and interviews and questionnaires.

When the data analysis of the studies conducted for STEM education is examined, it is observed that parametric and nonparametric tests, content analysis, factor analysis and comparative analysis are frequently preferred. It is seen that all the studies examined in terms of validity and reliability have been laboring seriously on this issue with being positive.

From the above-mentioned results, the following suggestion can be made:

1. Studies are mainly on science education; mathematics, chemistry, classroom teachers, and studies on compilation can be said to have received less attention. For this reason, it may be advisable to concentrate these areas on STEM education. 
2. The majority of the studies on STEM education were made on ideas, thoughts, feelings and tendencies. However, there are not enough studies on material development, academic achievement, integrated education and attitude. From this point on, it can be suggested to work in the areas indicated.

3. When the sample selection of the studies is examined, it is understood that the researchers frequently prefer the students who are at the level of primary education with the students of higher education. It was determined that they did not do any studies with the students at high school level. For this purpose, the selection of high school level as a sample in future studies will make a significant contribution to filling the gap in the relevant field.

4. When the STEM studies are analyzed in terms of analysis methods, it is seen that qualitative and quantitative methods are frequently preferred and mixed methods are less preferred. This is due to the fact that the processes of managing mixed methods are more demanding and require experience. For this purpose, increasing the studies on mixed methods will meet a big need in this field.

\section{References}

Akgündüz, D., Aydeniz, M., Çakmakçı, G., Çavaş, B., Çorlu, M., Öner, T., \& Özdemir, S. (2015). STEM eğitimi Türkiye raporu: "Günümüz modası mı yoksa gereksinim mi?". İstanbul: İstanbul Aydın Üniversitesi.

Bybee, R. W. (2011). Scientific and engineering practices in k-12 classrooms: Understanding "a framework for k-12 science education. Science and Children, 49(4), 10-16.

Çakıroğlu, E. (2016). STEM education textbook. Ankara.

Çalık, M., \& Sözbilir, M. (2014). İçerik analizinin parametreleri. Eğitim ve Bilim, 39(174), 33-38.

Çalık, M., Ayas, A., \& Ebenezer, J. V. (2005). A review of solution chemistry studies: Insights into students' conceptions. Journal of Science Education and Technology, 14(1), 29-50. https://doi.org/10.1007/s10956-005-2732-3

Çelik, H., Pektaş, H. M., \& Karamustafaoğlu, O. (2018). Science teaching laboratory applications: Common knowledge construction, learning cycle models and STEM approach. International Journal on New Trends in Education and Their Implications, 9(3), 11-29.

Çiltaş, A., Güler, G., \& Sözbilir, M. (2012). Türkiye'de matematik eğitimi araştırmaları: İçerik analizi çalışması. Kuram ve Uygulamada Eğitim Bilimleri, 12(1), 515-580.

Çorlu, M. (2013). Uzman alan ögretmeni eğitimi modeli ve görüşler. http://fetemm.tstem.com/gorusler

Çorlu, M. S., Capraro, R. M., \& Capraro, M. M. (2014). Introducing STEM education: implications for educating our teachers for the age of innovation. Education and Science, 39(171), 74-85.

Çorlu, M., \& Aydın, E. (2016). Evaluation of learning gains through integrated STEM projects. International Journal of Education in Mathematics, Science and Technology, 4(1), 20-29. https://doi.org/10.18404/ijemst.35021

Daugherty, J. (2012). Infusing engineering concepts: Teaching engineering design. National Center for Engineering and Technology Education.

Daugherty, M. K. (2009). The “T” and "E” in STEM. In ITEEA (Ed.), The Overlooked STEM Imperatives: Technology and Engineering (pp.18-25). Reston, VA: ITEEA.

Ercan, İ., \& Kan, İ. (2004). Ölçeklerde güvenirlik ve geçerlik. Uludağ Üniversitesi Tip Fakültesi Dergisi, 30(3), 211-216.

Gülgün, C. (2014). Sınıf Öğretmenlerinin Fen Öğretimine Yönelik Tutumları ile Görüşlerinin Fen Başarıları Arasındaki İlişkinin Araştırılması (Sivas). Yayınlanmamış Yüksek Lisans Tezi, Kastamonu Üniversitesi Fen Bilimleri Enstitüsü, Kastamonu.

Gülgün, C., Yılmaz, A., \& Çağlar, A. (2017). Teacher opinions about the qualities required in STEM activities applied in the science course. Journal of Current Researches on Social Sciences (JoCReSS), 7(1). 460-478.

Gülhan, F., \& Şahin, F. (2016). Fen-teknoloji-mühendislik-matematik entegrasyonunun (STEM) 5. sınıf öğrencilerinin bu alanlarla ilgili alg1 ve tutumlarma etkisi. International Journal of Human Sciences, 602-620. https://doi.org/10.14687/ijhs.v13i1.3447

Hernandez, P. R., Bodin R., Elliott, J. W., Ibrahim B., Rambo-Hernandez, K. E., Chen T. W., \& Miranda M. A. (2014). Connecting the STEM dots: measuring the effect of an integrated engineering design intervention. International Journal Technology Design Education. 24, 107-120. https://doi.org/10.1007/s10798-013-9241-0

Honey, M., Pearson, G., \& Schweingruber, H. (2014). STEM integration in K-12 education: Status, prospects and anagenda for research. N. A. Council. The National Academies Press. 
Katehi, L., Pearson, G., \& Feder, M. (Eds.) (2009). National Academy of Engineering and NationalResearch Council Report: Engineering in K-12 education. Washington, D.C. The NationalAcademies Press.

Langdon, D., Mckittrick, G., Beede, D., Khan, B., \& Doms, M. (2011). STEM: Good jobs now and for the future, U.S. Department of Commerce Economics and Statistics Administration, 3(11), 2.

Lederman, N., \& Niess, M. (1997). Less is more? More or less. School Science and Mathematics, 97(7), 341-343. https://doi.org/10.1111/j.1949-8594.1997.tb17374.x

McMillan, J.H., \& Schumacher, S. (2009). Research in education: Evidence-based inquiry (7th edt.). London: Pearson.

Moore, T., \& Richards L. G. (2012). P-12 engineering education research and practice. Introduction to a Special Issue of Advances in Engineering Education, 3 (2), 1-9.

Özdamar, K. (2003). Modern bilimsel araştırma yöntemleri. Eskişehir: Kaan Kitabevi.

Özdemir, S. (2016). STEM eğitimi için görüşler. Ankara.

Roberts, A. (2012). A justification for STEM education. Technology and engineering teacher.

Sandelowski, M., \& Barroso J. (2007). Handbook for synthesizing qualitative research. New York: Springer.

Şahin, A., Ayar, M. C., \& Adıgüzel, T. (2014). Fen, teknoloji, mühendislik ve matematik içerikli okul sonrası etkinlikler ve öğrenciler üzerindeki etkileri. Kuram ve Uygulamada Eğitim Bilimleri, 14(1), 1-26.

Walsh, D., \& Downe, S. (2005). Meta-synthesis method for qualitative research: A literature review. Journal of Advanced Nursing, 50(2), 204-211. https://doi.org/10.1111/j.1365-2648.2005.03380.x

Yıldırım, B., \& Altun, Y. (2015). STEM eğitimi ve mühendislik uygulamalarının fen bilgisi laboratuar dersindeki etkilerinin incelenmesi. El-Cezerî Fen ve Mühendislik Dergisi, 2(2), 28-40.

Yılmaz, A. (2012). Öğretmen Adaylarının Elektrokimya Konusunda Anlayışlarının Belirlenmesi. Yayınlanmış Yüksek Lisans Tezi, Atatürk Üniversitesi Ĕ̈itim Bilimleri Enstitüsü, Erzurum.

Y1lmaz, A. (2016). Approaches towards to higher education quality and accreditation: A meta-analysis application made up until 2016 year. Journal of Current Researches on Social Sciences (JoCReSS), 6(1), 33-54.

Yılmaz, A., \& Bayrakçeken, S. (2015). Determining of the prospective teachers' understadings of electrochemistry. International Conference On New Horizons In Education (INTE 2014), Procedia-Social and Behavioral Sciences, 174(2015), 2831-2838. https://doi.org/10.1016/j.sbspro.2015.01.975

Yılmaz, A., Gülgün, C., \& Çağlar, A. (2017). Teaching with STEM applications for 7th class students unit of "Force and Energy": Let's make a parachute, water jet, catapult, intelligent curtain and hydraulic work machine (bucket machine) activities. Journal of Current Researches on Educational Studies (JoCuRES), 7(1), 98-116.

\section{Appendix 1: Articles included in the study}

1.Eroğlu, S., \& Bektaş, O. (2016). STEM eğitimi almış fen bilimleri öğretmenlerinin stem temelli ders etkinlikleri hakkındaki görüşleri. Eğitimde Nitel Araştırmalar Dergisi - Journal of Qualitative Research in Education, 4(3), 43-67. [Online] www.enadonline.com DOI :10.14689/issn.2148-2624.1.4c3s3m

2.Baran, E., Canbazoğlu-Bilici, S., \& Mesutoğlu, C. (2015). Science, technology, engineering, and mathematics (STEM) public service announcement (psa) development activity. Araştırma Temelli Etkinlik Dergisi, 5(2), 60-69.

3.Aslan-Tutak, F., Akaygün, S., \& Tezsezen, S. (2017). Collaboratively learning to teach STEM: Change in participating preservice teachers' awareness of STEM. Hacettepe University Journal of Education. DOI: 10.16986/HUJE.2017027115

4.Gülhan, F., \& Şahin, F. (2016). Fen-teknoloji-mühendislik-matematik entegrasyonunun (STEM) 5. sinıf öğrencilerinin bu alanlarla ilgili algı ve tutumlarına etkisi. International Journal of Human Sciences, 13(1), 602-620. DOI:10.14687/ijhs.v13i1.3447

5.Marulcu, İ., \& Sungur, K. (2012). Fen bilgisi öğretmen adaylarının mühendis ve mühendislik algılarının ve yöntem olarak mühendislik-dizayna bakış açılarının incelenmesi. Afyon Kocatepe Üniversitesi Fen Bilimleri Dergisi, 13-23.

6.Yamak, H., Bulut, N., \& Dündar, S. (2014). The impact of STEM activities on 5th grade students' scientific process skills and their attitudes towards science. Gazi Universitesi Ë̆itim Fakültesi Dergisi, 34(2), 249-265. 
7.Ercan, S., \& Şahin, F. (2015). The usage of engineering practices in science education: effects of design based science learning on students' academic achievement. Necatibey Faculty of Education Electronic Journal of Science and Mathematics Education, 9(1), 128-164.

8.Bozkurt-Altan, E., Yamak, H., \& Buluş-Kırıkkaya, E. (2016). A proposal of the STEM education for teacher training: Design based science education. Trakya Üniversitesi Eğitim Fakültesi Dergisi, 6(2), 212-232.

9.Haciömeroğlu, G., \& Bulut, A.S. (2016). Integrative STEM teaching intention questionnaire: A validity and relaibility study of the turkish form. Journal of Theory and Practice in Education, 12(3), 654-669.

10.Şahin, A., Ayar, M. C., \& Adıgüzel, T. (2014). STEM related after-school program activities and associated outcomes on student learning. Educational Sciences: Theory \& Practice, 14(1), 309-322. DOI:10.12738/estp.2014.1.1876

11.Corlu, M. S., Capraro, R. M., \& Çorlu, M. A. (2015). Investigating the mental readiness of pre-service teachers for integrated teaching. International Online Journal of Educational Sciences, 7(1), 17-28. DOI:http://dx.doi.org/10.15345/iojes.2015.01.002

12.Akgündüz, D., Aydeniz, M., Çakmakçı, G., Çavaş, B., Çorlu, M. S., Öner, T., \& Özdemir, S. (2015). STEM Eğitimi Türkiye Raporu: Günün Modası mı Yoksa Gereksinim mi?. İstanbul: İstanbul Aydın Üniversitesi.

13.Batı, K., Çalışkan, İ., \& Yetişir, M. İ. (2017). Computational thinking and integrative education (STEAM) in science education. Pamukkale Üniversitesi Eğitim Fakültesi Dergisi, 41, 91-103. DOI: http://dx.doi.org/10.9779/PUJE800

14.Buyruk, B., \& Korkmaz, Ö. (2016). STEM awareness scale (SAS): Validity and reliability study. Journal of Turkish Science Education, 13(2), 61-76. DOI: 10.12973/tused.10179a

15.Yıldirım, B., \& Altun, Y. (2015). Investigating the effect of STEM education and engineering applications on science laboratory lectures. El-Cezerî Journal of Science and Engineering 2(2), 28-40.

16.Çınar, S., Pırasa, N., Uzun, N., \& Erenler, S. (2016). The effect of STEM education on pre-service science teachers' perception of interdisciplinary education. Journal of Turkish Science Education, 13(special issue), 118-142. DOI:10.12973/tused.10175a

17.Keçeci, G., Alan, B., \& Kırbağ-Zengin, F. (2017). STEM education practices with 5th grade students. Ahi Evran Üniversitesi Kırşehir Eğitim Fakültesi Dergisi (KEFAD), 18(özel sayı), 1-17.

18.Tezel, Ö., \& Yaman, H. (2017). A review of studies on STEM education in Turkey. Journal of Research in Education and Teaching, 6(1), 135-145.

19.Yılmaz, A., Gülgün, C., \& Çağlar, A. (2017). Teaching with STEM applications for 7th class students unit of "Force and Energy": Let's make a parachute, water jet, catapult, intelligent curtain and hydraulic work machine (bucket machine) activities. Journal of Current Researches on Educational Studies (JoCuRES), 7(1). 98-116.

20.Gülgün, C., Yılmaz, A., \& Çağlar, A. (2017). Teacher opinions about the qualities required in STEM activities applied in the science course. Journal of Current Researches on Social Sciences (JoCReSS), 7(1), 460-478.

\section{Copyrights}

Copyright for this article is retained by the author(s), with first publication rights granted to the journal.

This is an open-access article distributed under the terms and conditions of the Creative Commons Attribution license which permits unrestricted use, distribution, and reproduction in any medium, provided the original work is properly cited. 